\title{
P-element-mediated enhancer detection: a versatile method to study development in Drosophila
}

\author{
Hugo J. Bellen, ${ }^{1}$ Cahir J. O'Kane, ${ }^{2}$ Clive Wilson, Ueli Grossniklaus, Rebecca Kurth Pearson, and \\ Walter J. Gehring \\ Department of Cell Biology, Biozentrum, University of Basel, $\mathrm{CH} 4056$ Basel, Switzerland
}

\begin{abstract}
We generated and characterized $>500$ Drosophila strains that carry single copies of a novel P-element enhancer detector. In the majority of the strains, the $\beta$-galactosidase reporter gene in the P-transposon responds to nearby transcriptional regulatory sequences in the genome. A remarkable diversity of spatially and temporally regulated staining patterns is observed in embryos carrying different insertions. We selected numerous strains as markers for different embryonic organs, tissues, and cells. Many of these strains should allow the study of complex developmental processes, such as nervous system development, which have not been convenient to analyze previously. Also, we present genetic evidence that some of the detected regulatory elements control nearby Drosophila genes. In light of our results, we discuss the diversity and complexity of cis-acting regulatory elements in the genome and the general applications of the enhancer detector method for the study of Drosophila development.
\end{abstract}

[Key Words: Development; P element; $\beta$-galactosidase; cell markers: cis-acting elements; Drosophila]

Received March 24, 1989; revised version accepted July 14,1989.

One of the primary aims of modern biology is to elucidate the molecular mechanisms of development in higher eukaryotes. Genetic approaches have been especially successful in furthering our understanding of such mechanisms. These successes have been largely achieved using nonvertebrates as model systems, because vertebrates are generally not amenable to genetic analysis. Genetic studies with the fruitfly, Drosophila melanogaster, have been particularly important in allowing numerous genes involved in the control of development to be identified and isolated. Many of the products of these genes share sequence similarities with vertebrate gene products (for review, see Gehring and Hiromi 1986). Therefore, it seems likely that studies of developmental processes in Drosophila will play a central role in our understanding of similar processes in more complex eukaryotes.

Genetic analyses of embryogenesis in Drosophila typically have focused on maternal-effect and embryonic lethal genes because many of these are likely to play key roles in development. The most extensive studies have involved systematic screens of mutations in these genes, in which each mutation is tested for its effects on easily identifiable morphological structures. Previous screens of embryonic lethal mutations mainly have been based on the identification of genes that affect larval cuticular structures, many of which participate in the establish-

Present addresses: ${ }^{1}$ Institute for Molecular Genetics, Baylor College of Medicine, Houston, Texas, 77030 USA.; ${ }^{2}$ Department of Biological Sciences, University of Warwick, Coventry CV4 7AL, UK. ment of the segmented body plan (Jürgens et al. 1984; Nüsslein-Volhard et al. 1984; Wieschaus et al. 1984). Nearly $90 \%$ of the estimated 1250 essential embryonic genes have no effect on cuticular phenotype (Wieschaus et al. 1984). Many of these genes may be involved in specific developmental events that only affect the internal structures of the embryo. However, the opacity of the embryonic cuticle and the complexity of morphogenetic movements in Drosophila have precluded a systematic genetic analysis of the development of internal embryonic structures. For such an analysis to be possible, new techniques must be developed to allow easy identification of internal tissues and cells.

In a limited number of cases, antibodies have been generated that serve as good markers for internal tissues and cells of Drosophila. Some of these antibodies have been indispensable tools in the identification and analysis of genes that affect cells or tissues recognized by these antibodies (Jan and Jan 1982; Bodmer et al. 1987; Thomas et al. 1988). Unfortunately, a sytematic screen for markers of this kind involves the generation and analysis of numerous antibodies, which is extremely time-consuming.

An alternative method to produce tissue- and cell-specific markers in Drosophila has been described recently (O'Kane and Gehring 1987). This system makes use of the $\beta$-galactosidase $($ lac $Z$ ) gene of Escherichia coli as a reporter gene (Lis et al. 1983). A translational fusion of lac $Z$ to the P-transposase gene places the expression of $\beta$-galactosidase under the control of the weak, constitu- 
tive P-transposase promoter. This fusion gene is part of a P-element construct that can be integrated at different locations in the Drosophila genome. The P-transposase promoter may be influenced by nearby genomic regulatory elements that impose temporal and spatial regulation on the fusion gene. This regulation can be visualized in whole-mount embryos by staining with a chromogenic substrate.

We have undertaken an extensive screen with the transposon $\mathrm{P}[\mathrm{lArB}]$, one member of a second generation of more versatile P-element constructs containing the PlacZ fusion gene (Wilson et al. 1989). A recently developed procedure involving simple genetic crosses has been used to generate many independent fly strains carrying single insertions at new locations /Cooley et al. 1988; Robertson et al. 1988). A great variety of staining patterns have been observed, showing that the P-lacZ fusion gene can come under the control of many different regulatory elements; remarkably, the fusion gene is expressed in a spatially and temporally restricted fashion in $\sim 65 \%$ of the strains. We believe that a large number of the detected regulatory elements are enhancers, i.e., control sequences that can act at a distance from a promoter and that frequently impose tissue-specific regulation on genes (Serfling et al. 1985). Therefore, we describe our technique as P-element-mediated enhancer detection. Many strains have been recovered in which specific internal tissues or cells are marked. They will prove valuable as markers in screening for mutations that affect internal embryonic structures. We present a genetic analysis indicating that some insertions are at the same chromosomal location as a gene with a similar expression pattern to that of the P-lacZ fusion gene. In Wilson et al. (1989), a molecular analysis is presented, showing that the $\beta$-galactosidase expression pattern does indeed reflect the expression pattern of a nearby gene in a significant number of strains. Hence, P-element-mediated enhancer detection screens have multiple applications in the study of Drosophila development.

\section{Results}

\section{Generation of new strains carrying an enhancer detector}

A novel enhancer detector plasmid, P-lArB (Wilson et al. 1989), carrying the OOSy $^{+}\left(\mathrm{ry}^{+}\right)$eye color marker was injected into ry ${ }^{506}$ embryos, and five independent $r y^{+}$ transformant lines were established. One of these transformants, designated $\mathrm{P}[1 \mathrm{ArB}] 6$, has a single insertion on the second chromosome. To mobilize the insertion in this strain to new chromosomal locations, we employed the 'jumpstart technique' (Cooley et al. 1988). The jumpstart scheme is summarized in Figure 1. In brief, flies carrying a stable genomic P-transposase source, $\mathrm{P}\left[\mathrm{ry}^{+} \Delta 2-3\right]$ (99B) (E\#2 strain; Robertson et al. 1988), were crossed to the $\mathrm{P}[\mathrm{IArB}] 6$ transformant strain (see Materials and methods). The progeny were screened for males carrying both the transposase gene and the $\mathrm{P}[\mathrm{ArB}] 6$ insertion. These males are referred to as jump-

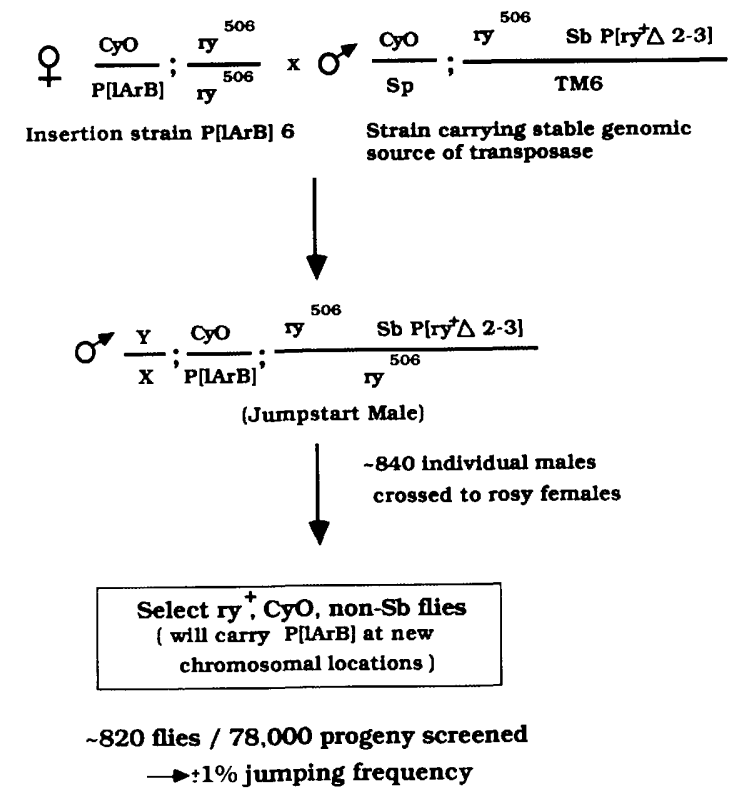

Figure 1. The jumpstart scheme (for more details, see Materials and methods।.

start males. The $\Delta 2-3$ transposase in the germ-line cells of these males can excise P[lArB] and, in some cases, insert it at new locations. Using appropriate genetic markers, progeny carrying new insertions were identified (see Fig. 1). We recovered such strains with insertions on the $\mathrm{X}$ chromosome, on the second chromosome balancer $\mathrm{CyO}$, or on a third chromosome marked with $r y^{506}$. Because the new insertions were produced by transposition events, we named the resulting insertion strains 'transposants'.

To characterize the transposants, each chromosome containing an insertion was balanced /see Materials and methods). Of a total of 623 balanced transposants analyzed, 537 independent lines were established. The other 86 transposants were eliminated because they showed the same $\beta$-galactosidase expression pattern as a sibling transposant. It was inferred that each of these transposants carried an insertion at the same location as the sibling strain and thus was the result of the same premeiotic transposition event in the germ line of the father as its sibling. We recovered 65 insertions on the $\mathrm{X}$ chromosome, 233 on the $\mathrm{CyO}$ balancer chromosome, and 238 on the $r y^{506}$ chromosome.

We identified recessive lethal, visible, and male and female sterile mutations for the first and third chromosome transposants. Such mutations could not be characterized on the second chromosome because the $\mathrm{CyO}$ chromosome is homozygous lethal. Our results are summarized in Table 1. Because jumpstart males have only one $\mathrm{X}$ chromosome and are viable, the $\mathrm{X}$-linked lethal mutations must have been generated in the germ line of these males and are most likely caused by the P-element insertion. This hypothesis is supported by genetic analysis of two of the three transposants (data not shown). However, some of the lethal, visible, and sterile mutations on the third chromosome are not caused by 
Table 1. Visible, lethal, and sterile mutations

\begin{tabular}{cccccc}
\hline & \multicolumn{4}{c}{ Mutations } \\
\cline { 2 - 5 } Chromosome & total & lethal & female & male & visible \\
\hline 1 & 67 & 3 & 1 & 0 & 0 \\
3 & 254 & $91(49)^{\mathbf{a}}$ & $9^{\mathrm{a}}$ & $6^{\mathrm{a}}$ & $8^{\mathrm{a}}$ \\
\hline
\end{tabular}

a Some of the third chromosome mutations may not be associated with a $\mathrm{P}[\mathrm{lArB}]$ insertion (e.g., at least 42 of the lethal mutations are not P-element-related; see text).

$\mathrm{P}[\mathrm{lArB}]$. Forty-two of the 91 lethal mutations on this chromosome fall into three complementation groups. For a representative strain from each of these groups, it was possible to recombine the lethal mutation away from $\mathrm{P}[\mathrm{lArB}]$ (see Materials and methods), showing that the insertion and lethal mutation are not associated. The mutations were probably present in some of the $r y^{506}$ chromosomes of the $\mathrm{P}[\mathrm{lArB}] 6$ transformant strain prior to mobilization, because we decided not to isogenize the third chromosome before the jumpstart experiment was initiated. If $\mathrm{P}[\mathrm{lArB}]$ is responsible for the lethal phenotype in the remaining 49 strains, precise excision of $\mathrm{P}[\mathrm{lArB}]$ should reverse the lethality. $\mathrm{P}[\mathrm{lArB}]$ was excised from 18 of these strains using the $\Delta 2-3$ transposase strain (see Materials and methods). For 15 transposants, homozygous viable $r y^{506}$ flies were recovered, suggesting that a P-element was responsible for the lethality. Southern analyses of genomic DNA from four transposants and in situ hybridization to chromosomes of three others using a P-element probe indicated that $\mathrm{P}[\mathrm{lArB}]$ is the only P-element present in these strains. Therefore, we conclude that 15 of the 18 transposants tested are lethal because of the $\mathrm{P}[\mathrm{lArB}]$ insertion. Hence, we estimate that $20 \%$ of the insertions on the third chromosome, at most, cause lethality. This figure is significantly higher than the $5 \%$ lethal mutations recovered on the X chromosome. We have no simple explanation for this discrepancy, but similar observations have been reported previously (Simmons et al. 1985; Cooley et al. 1988; for further discussion, see Engels 1988).

\section{$P[1 A r B]$ transposants exhibit a great variety of staining patterns}

We analyzed the $\beta$-galactosidase expression patterns of 0 - to 18 -hr-old embryos for 623 transposant strains. A vast array of spatially and temporally regulated expression patterns was observed. Staining patterns of several transposants are shown in Figure 2.

A summary of the embryonic staining patterns and frequencies at which particular tissues express $\beta$-galactosidase is shown in Table 2. As can be seen in Table 2a, only about $5 \%$ of the transposants do not express $\beta$-galactosidase during embryonic development. Approximately $30 \%$ stain in all tissues 'all over', but there is a wide range of staining intensities within this group. Many transposants that stain weakly in all parts of the embryo stain more strongly in particular tissues or cells. About $8 \%$ of the transposants express $\beta$-galactosidase before cellular blastoderm. Because very few genes are active transcriptionally at this time, such transposants would be expected to express the $l a c Z$ fusion gene in the female ovary. $\beta$-Galactosidase has been detected in nurse cells and late-stage oocytes in the ovaries of females from many of these strains (Grossniklaus et al. 1989).

About $30 \%$ of the transposants share a characteristic pattern of lacZ expression, which we refer to as the 'repeated pattern.' In these strains the lac $Z$ gene is expressed at germ-band extension, both anterior to the cephalic furrow and in the posterior dorsal epidermis of each segment. Expression is strongest in alternate segments, i.e., the second thoracic segment (T2) and the first, third, fifth, and seventh abdominal segments (Al, A3, A5, A7; data not shown). The repeated pattern is weaker than most cell- or tissue-specific patterns and frequently is superimposed on other patterns. This pattern has been observed previously in other transformants that carry $\mathrm{P}$-elements that contain $l a c Z$ and rosy ${ }^{+}$ (Ghysen and O'Kane 1989). Because the insertion position in several of our strains is different, it would appear that regulatory sequences within the $P[1 \mathrm{ArB}]$ construct are responsible partly for the repeated pattern. However, as most transposants do not exhibit the repeated pattern, the genomic environment clearly can modify the response of the P-transposase promoter to this regulation.

We estimate that $65 \%$ of all transposants show at least some degree of spatially specific staining. This figure includes strains that stain weakly all over or with a repeated pattern but that still show a superimposed tissue-specific pattern. The data shown in Table $2 \mathrm{~b}$ summarize the frequencies at which a particular organ or tissue is stained in these strains. Either all or a subset of cells in the different tissues may express $\beta$-galactosidase. Often, we observe quite complex patterns in which several different tissues are stained (e.g., Fig. 2DD). About $55 \%$ of all transposants express $\beta$-galactosidase in the head region. The cells that stain most frequently in the head are likely to be sensory organs of the developing embryo. We have not identified which sensory organs stain, but have noted in many cases that different strains do not stain identically. About $48 \%$ of transposants express $\beta$-galactosidase in cells of the central nervous system (CNS), whereas lacZ expression is found in $20 \%$ of the cells of the peripheral nervous system (PNS). However, very few transposants stain most or all cells of the PNS. A total of only $5 \%$ of transposants show staining in fat body cells, muscle, and other mesodermal derivatives. Table $2 \mathrm{c}$ summarizes the frequencies of transposants that stain essentially only one embryonic tissue. These strains make up $15 \%$ of the total number of transposants and include marker strains for many different tissues.

\section{Markers for different embryonic tissues and cells}

Strains in which the dominant $\beta$-galactosidase marker gene is expressed particularly strongly in a specific organ or tissue should be useful in studying the embryonic de- 

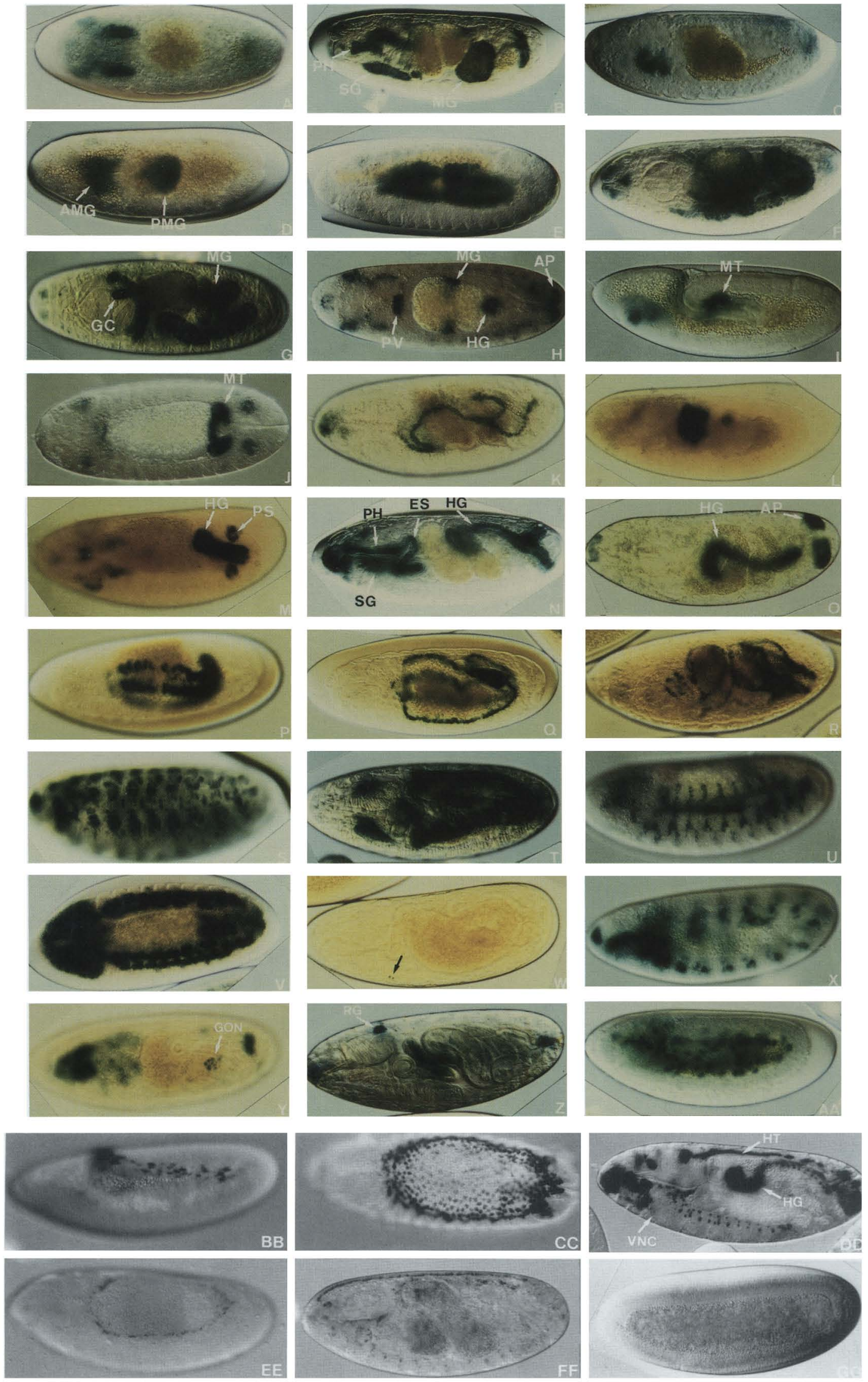

Figure 2. (See facing page for legend.) 
Table 2. Summary of the staining patterns of transposants

\begin{tabular}{|c|c|c|c|c|c|c|}
\hline \multirow[b]{2}{*}{ Chromosome } & \multirow[b]{2}{*}{$\begin{array}{l}\text { Total number of } \\
\text { transposants }\end{array}$} & \multicolumn{3}{|c|}{ (a) Nonspecific staining patterns $s^{2}$} & \multirow[b]{2}{*}{$\begin{array}{l}\text { All over } \\
\text { staining }\end{array}$} & \multirow[b]{2}{*}{$\begin{array}{c}\text { Repeated } \\
\text { pattern }\end{array}$} \\
\hline & & $\begin{array}{c}\text { No } \\
\text { staining }\end{array}$ & $\begin{array}{l}\text { Preblastoderm } \\
\text { staining }\end{array}$ & $\begin{array}{c}\text { Blastoderm } \\
\text { staining }\end{array}$ & & \\
\hline 1 & 65 & 1 & 9 & 2 & 27 & 17 \\
\hline 2 & 233 & 12 & 13 & 15 & 59 & 73 \\
\hline 3 & 238 & 9 & 24 & 14 & 83 & 71 \\
\hline Total & 536 & 22 & 46 & 31 & 169 & 161 \\
\hline
\end{tabular}

(b) Specific staining pattern $s^{\mathbf{a}, \mathrm{c}}$

\begin{tabular}{ccccccrrr} 
& Total & Part & & & & & & \\
Chromosome & CNS & CNS & PNS & Head & Foregut & Midgut & Hindgut & Mesoderm \\
\hline 1 & 22 & 12 & 16 & 47 & 4 & 4 & 4 & 11 \\
2 & 47 & 50 & 30 & 102 & 15 & 23 & 11 & 15 \\
3 & 70 & 57 & 59 & 144 & 32 & 47 & 30 & 29 \\
Total & 139 & 119 & 105 & 293 & 51 & 74 & 30 \\
\hline
\end{tabular}

(c) Highly specific staining patterns $s^{\mathbf{a}, \mathbf{d}}$

\begin{tabular}{cccccccc} 
Chromosome & $\begin{array}{c}\text { Total } \\
\text { CNS }\end{array}$ & $\begin{array}{c}\text { Total CNS } \\
\text { and head }\end{array}$ & $\begin{array}{c}\text { Part } \\
\text { CNS }\end{array}$ & $\begin{array}{c}\text { PNS } \\
\text { and head }\end{array}$ & Head & Gut & Mesoderm \\
\hline 1 & 1 & 2 & 0 & 2 & 4 & 0 & 0 \\
2 & 1 & 8 & 7 & 3 & 20 & 3 & 2 \\
3 & 0 & 2 & 3 & 6 & 14 & 2 & 1 \\
Total & 2 & 12 & 10 & 11 & 38 & 5 \\
\hline
\end{tabular}

a Single transposants can be listed in more than one section of the table.

b Staining first in the cellular blastoderm; only three of these transposants stain in a spatially restricted pattern at this stage.

c May stain in more than one tissue.

d Staining in essentially only one cell type or tissue.

velopment of these organs and tissues in Drosophila. Many internal organs or tissues are not identified easily with conventional microscopy techniques in the absence of any staining. Therefore, we focused our attention on the characterization of markers for these internal structures. Table 3 lists a selection of transposants that may be used as tissue-specific marker strains. A more extensive list is available on request. Staining patterns of many of the marker strains are shown in Figure 2. Staining appears to be confined to the nuclei in most tissues. This can be seen easily in large cells and nuclei, such as those of the amnioserosa (Fig. 2CC). Examination of histological sections of adult ovaries has confirmed that, at least in this tissue, $\beta$-galactosidase is localized to the nucleus (Grossniklaus et al. 1989). In many cases, this property is useful, as it facilitates tissue identification and improves resolution. The fusion protein presumably is targeted to the nucleus because it contains the amino-terminal end of the $\mathrm{P}$ transposase, which is thought to be a nuclear protein.

In a large number of transposants, only subsets of cells in a particular organ are stained. For example, only the germ-line cells of the gonads are stained in the embryo shown in Figure 2Y. Many insertion strains express $\beta$ galactosidase in cells that we have not been able to identify yet, for example, mesodermal derivatives in the embryos shown in Figure 2, $U$ and $V$. The embryo shown in Figure $2 \mathrm{~W}$ expresses $\beta$-galactosidase in two unidentified

Figure 2. Staining patterns of selected marker transposant strains. Embryos were stained for $\beta$-galactosidase activity, as described in Materials and methods. All strains are described in Table 3. In many of the strains, it is clear that $\beta$-galactosidase is localized to the nucleus (e.g., $C C$ ). The tissues that are marked clearly in each transposant and the developmental stage of each embryo are given below. In all cases anterior is to the left and dorsal is at the top, unless stated otherwise. (A) A66.2F3, ventral view (salivary glands; stage 14); (B) A 189.2F3, ventrolateral view (salivary glands, pharynx, some of midgut, Malpighian tubules, some of CNS; stage 16); $(C)$ $\mathrm{A} 418.1 \mathrm{M} 2$ (foregut; stage 15$) ;(D, E$, and $F) \mathrm{A} 490.2 \mathrm{M} 3$ (midgut; stages 10,13 , and 17 , respectively); $(G) \mathrm{Cl} 1.2 \mathrm{~S} 3$, ventral view $($ some of midgut; stage 17); $(H)$ B $72.1 \mathrm{M} 3$, ventral view (some of midgut, some of hindgut, anal pads; stage 14); (I) A289.1F1 (Malpighian tubules; stage 11); (/) A203.3F2, dorsal view (Malpighian tubules; stage 13); (K) A154.2M3 (Malpighian tubules; stage 17); $(L, M$, and $N)$ A4.1M2 (salivary gland, foregut, hindgut, posterior spiracles; stages 11,13 , and 17 , respectively); (O) 374.2F1, ventrolateral view (hindgut, anal pads; stage 17); $(P, Q$, and $R$ ) A176.1M2 (visceral mesoderm; stages 13, 15, and 17, respectively); $(S)$ B21.1M3 (muscles; stage 16); (T) A79.1M2, dorsolateral view (fat body; stage 17); $(U$ and $V)$ A409.1F31 (other mesoderm; $V$ is a dorsal view; stage 14); $(W)$ B1.2M3 (two cells in CNS; stage 17); $(X)$ B52.1M3 (PNS; stage 11) (Y) A495.1M2 (pole cells in gonads; stage 17); (Z) A457.1F2 (corpora cardiaca of ring gland; stage 17); $(A A)$ B39.1M2 (yolk cells; stage 11$) ;(B B, C C$, and $D D \mid$ A308.1F3 (hindgut, some of CNS, amnioserosa/heart; $C C$ is a dorsal view; stages 10,13 , and 17 , respectively); $(E E$ and $F F)$ B48.1 M3 (cells at boundary of amnioserosa and dorsal epidermis; $E E$ is a dorsolateral view; stages 13 and 17 , respectively); $(G G)$ B24.2M2 (early zygotic marker on $C y O$; stage 5 ). Abbreviations are as in Table 3. 
Table 3. Tissue-and cell-specific marker strains

\begin{tabular}{|c|c|c|c|c|c|}
\hline Tissue marked & Strain & Stage & Map position & $\begin{array}{l}\text { Other tissues } \\
\text { and remarks }\end{array}$ & Figure \\
\hline \multicolumn{6}{|l|}{ Gut and annexes } \\
\hline \multirow[t]{3}{*}{ salivary glands } & A4.1M2 & 13 & $50 \mathrm{D}$ & $\begin{array}{l}\mathrm{PH}, \mathrm{ES}, \mathrm{H} \\
\quad F G, P S, H G\end{array}$ & $2 \mathrm{~L}, \mathrm{M}, \mathrm{N}$ \\
\hline & $\mathrm{A} 66.2 \mathrm{~F} 2$ & 12 & & $\mathrm{H}$ & $2 \mathrm{~A}$ \\
\hline & $\mathrm{A} 189.2 \mathrm{~F} 3$ & 16 & $95 \mathrm{~A}$ & $\begin{array}{l}\text { MT, Pcns, PS, H, } \\
\text { PMG, PH }\end{array}$ & $2 B$ \\
\hline foregut & $\mathrm{A} 418.1 \mathrm{M} 2$ & 14 & & $\underline{\mathrm{PH}}, \mathrm{ES} ; \mathrm{HG}$ & $2 \mathrm{C}$ \\
\hline midgut (all) & A490.2M3 & 10 & & $\overline{\mathrm{H}}$ & $2 \mathrm{D}, \mathrm{E}, \mathrm{F}$ \\
\hline \multirow[t]{5}{*}{ parts of midgut } & $\mathrm{Al} 68.1 \mathrm{~F} 1$ & 14 & $1 \mathrm{C}$ & $\begin{array}{l}\text { PNS, H, PMG, HG, } \\
\text { Mu/Glia } \\
\text { flanking VNC, } \\
\text { Pcns(MNC) }\end{array}$ & \\
\hline & $\mathrm{P}\left[\right.$ lac,ry $\mathrm{H}^{+} \mid \mathrm{A} 48$ & 12 & $17 \mathrm{C}^{\mathrm{a}}$ & $\frac{\text { Ant. PMG }}{\mathrm{H}, \mathrm{Sp}}$, Pcns, & \\
\hline & $\mathrm{A} 128.1 \mathrm{~F} 3^{\mathrm{b}}$ & & $61 \mathrm{~F}$ & $\underline{\mathrm{PV}}, \mathrm{HG}, \mathrm{AP}, \mathrm{SegB}$ & \\
\hline & $\mathrm{B} 72.1 \mathrm{M} 31$ & 13 & & $\frac{\overline{\text { rings in } \mathrm{PV} \text { and }}}{\underline{\mathrm{MG}}, \mathrm{HG}, \mathrm{PS}, \mathrm{AP}}$ & $2 \mathrm{H}$ \\
\hline & $\mathrm{C} 11.2 \mathrm{~S} 3$ & 16 & & $\mathrm{G} \overline{\mathrm{C}, \mathrm{PMG}}$ & $2 \mathrm{G}$ \\
\hline \multirow{3}{*}{$\begin{array}{l}\text { Malpighian } \\
\text { tubules }\end{array}$} & $\mathrm{A} 289.1 \mathrm{~F} 1$ & 10 & & $\overline{\mathrm{H}, \text { Pcns, PNS }}$ & $2 \mathrm{I}$ \\
\hline & A203.3F2 & 11 & & intersegmental pits & $2 J$ \\
\hline & A154.2M3 & 12 & & $\mathrm{H}$ & $2 \mathrm{~K}$ \\
\hline hindgut & A308.1F3 & 11 & $78 \mathrm{D}$ & $\begin{array}{l}\text { Pcns, PNS, } \mathrm{H}, A S \\
\quad \text { later } H T\end{array}$ & $2 \mathrm{BB}, \mathrm{CC}, \mathrm{D}$ \\
\hline \multirow[t]{2}{*}{ anal pads } & $\mathrm{A} 374.2 \mathrm{Fl}$ & 13 & $12 \mathrm{~B}$ & $\mathrm{H}, \mathrm{Sp}, H G$ & 20 \\
\hline & $\mathrm{B} 72.1 \mathrm{M} 31$ & 12 & & $\begin{array}{l}\frac{\text { ring in } \mathrm{HG}}{\mathrm{MG}, \mathrm{PV}}, \mathrm{ES}, H G \\
\end{array}$ & $2 \mathrm{H}$ \\
\hline \multicolumn{6}{|l|}{ Mesoderm } \\
\hline \multirow[t]{3}{*}{ muscles } & $\mathrm{P}[1 \mathrm{ArB}] 6$ & 14 & $54 \mathrm{~A} / \mathrm{B}$ & & \\
\hline & $\mathrm{B} 21.1 \mathrm{M} 3$ & & $70 \mathrm{~F}$ & & $2 S$ \\
\hline & $\mathrm{P}\left[1 a c, r y^{+}\right] \mathrm{A} 20$ & & $69 \mathrm{~B}$ & $\frac{\text { mesoderm staining }}{\frac{\text { from stage } 10}{\text { D.EP, Acns }}}$ & \\
\hline \multirow{2}{*}{$\begin{array}{l}\text { visceral } \\
\text { mesoderm }\end{array}$} & A176.1M2 & 12 & & & $2 P, Q, R$ \\
\hline & $\mathrm{A} 183.1 \mathrm{~F} 2$ & 12 & $36 \mathrm{E}$ & Cl, SegB & c \\
\hline \multirow[t]{2}{*}{ fat body } & A79.1M2 & 16 & & & $2 \mathrm{~T}$ \\
\hline & Al09.1F2 & 17 & $25 B / C$ & blood cells & c \\
\hline other mesoderm & A409.1F3 & 12 & & $\begin{array}{l}\mathrm{Tr} \text {; may be } \\
\text { identical to } \\
\text { A201.1M3 }\end{array}$ & $2 \mathrm{U}, \mathrm{V}$ \\
\hline \multicolumn{6}{|l|}{ Nervous system } \\
\hline \multirow[t]{2}{*}{ all CNS } & $\mathrm{P}\left[\right.$ lac,ry $\left.{ }^{+}\right] \mathrm{A} 49$ & 11 & $\mathrm{X}$ & $\mathrm{H}, \mathrm{Y}$ & d \\
\hline & A350.1M2 & 11 & $59 \mathrm{E} / \mathrm{F}$ & $\begin{array}{l}\text { AP rim, SG, H(EP), } \\
\text { AS/D.EP } \\
\text { boundary }\end{array}$ & \\
\hline \multirow[t]{5}{*}{ CNS subset } & $\mathrm{A} 107.1 \mathrm{~F} 3$ & 12 & $94 \mathrm{~B} / \mathrm{C}$ & $\frac{\text { Pcns glial cells, }}{\text { PNS }}$ & c \\
\hline & $\mathrm{A} 189.2 \mathrm{~F} 3$ & & $95 \mathrm{~A}$ & $\begin{array}{l}\frac{\text { paired cells in }}{\text { MNC, SG, PS, }} \\
\frac{\mathrm{H}, P M G, M T, P H}{}\end{array}$ & $2 B$ \\
\hline & A308.1F3 & 13 & & $\begin{array}{l}\text { AS/HT, HG, } \\
\text { PNS, H }\end{array}$ & $2 \mathrm{BB}, \mathrm{CC}, \mathrm{DD}$ \\
\hline & $\mathrm{B} 1.2 \mathrm{M} 3$ & & & $\begin{array}{l}2 \text { cells in thoracic } \\
\text { VNC }\end{array}$ & $2 W$ \\
\hline & $\mathrm{P}\left[1 a c, r y^{+}\right] \mathrm{A} 63$ & 10 & 97D & $\begin{array}{l}\frac{\text { MEC, SG, FG, HG, }}{M G}, \text { SegB }\end{array}$ & $3 \mathrm{~A}, \mathrm{~B}$ \\
\hline PNS & $\mathrm{B} 52.1 \mathrm{M} 3$ & 11 & $90 \mathrm{D}$ & much of PNS & c \\
\hline \multicolumn{6}{|l|}{ Other tissues } \\
\hline pole cells & $\begin{array}{l}\mathrm{A} 495.1 \mathrm{M} 2 \\
\mathrm{~A} 507.2 \mathrm{M} 2\end{array}$ & $\begin{array}{l}17 \\
17\end{array}$ & $35 \mathrm{DE}$ & $\begin{array}{l}\text { H, PS } \\
\text { B, PS }\end{array}$ & $2 \mathrm{Y}$ \\
\hline
\end{tabular}

Table 3. (Continued on following page.) 


\begin{tabular}{|c|c|c|c|c|c|}
\hline Tissue marked & Strain & Stage & Map position & $\begin{array}{l}\text { Other tissues } \\
\text { and remarks }\end{array}$ & Figure \\
\hline & $\mathrm{B} 49.1 \mathrm{M} 3$ & 17 & $87 \mathrm{~B} 6-12$ & $\mathrm{H}, \mathrm{PV}$ & \\
\hline blood & Al09.1F2 & 17 & $25 B / C$ & $\begin{array}{l}\text { FB (after blood } \\
\text { cells stain) }\end{array}$ & c \\
\hline $\begin{array}{l}\text { other scattered } \\
\text { cells }\end{array}$ & A409.1F3 & 17 & & Mes, $\operatorname{Tr}$ & $2 U, V^{f}$ \\
\hline ring gland & A457.1F2 & 17 & & $\frac{\text { corpora cardiaca, }}{\mathrm{H}, \mathrm{PNS}, \mathrm{PS}}$ & $2 z$ \\
\hline garland gland & $\mathrm{A} 247.1 \mathrm{M} 3 \mathrm{~L}^{\mathrm{e}}$ & 12 & $62 \mathrm{EF} ; 85 \mathrm{CD}$ & $\begin{array}{l}\text { MG, AP, Pcns, H, } \\
\text { HG, VM }\end{array}$ & \\
\hline $\begin{array}{l}\text { posterior } \\
\text { spiracles }\end{array}$ & A189.2F3 & & $95 \mathrm{~A}$ & $\begin{array}{l}\text { Pcns, MT, SG, PH, } \\
\text { H, MG }\end{array}$ & $2 B^{f}$ \\
\hline \multirow[t]{2}{*}{ trachea } & $\mathrm{A} 201.1 \mathrm{M} 3$ & 14 & $92 \mathrm{C}$ & $\begin{array}{l}\text { Mes, scattered } \\
\text { cells, other Mes }\end{array}$ & \\
\hline & A409.1F3 & 15 & & Mes, scattered cells & $2 \mathrm{U}, \mathrm{V}$ \\
\hline yolk & B39.1M2 & 12 & & & $2 \mathrm{AA}$ \\
\hline \multirow[t]{2}{*}{ amnioserosa } & A405.1M2 & 9 & $33 \mathrm{~A}$ & $\begin{array}{l}2 \text { stripes, from } \\
\text { blastoderm on }\end{array}$ & $3 E, F$ \\
\hline & $\mathrm{B} 48.1 \mathrm{M} 3$ & & & $\frac{\text { AS/D.EP }}{\text { boundary }}$ & 2EE, FF \\
\hline \multirow[t]{2}{*}{ unidentified } & $\mathrm{A} 53.1 \mathrm{M} 3$ & 14 & & $\begin{array}{l}13-16 \text { scattered } \\
\text { cells DL. to ES }\end{array}$ & \\
\hline & $\mathrm{P}[\mathrm{lArB}] 18$ & 11 & & $\begin{array}{l}\text { possibly cephalic } \\
\text { mesoderm }\end{array}$ & \\
\hline \multirow[t]{3}{*}{ other strains } & $\mathrm{A} 80.1 \mathrm{M} 2$ & Bla & & blue balancer & \\
\hline & $\mathrm{B} 24.2 \mathrm{M} 2$ & Bla & & blue balancer & $2 \mathrm{GG}$ \\
\hline & C40.1S3 & $8 / 9$ & & blue balancer & \\
\hline
\end{tabular}

Insertion strains selected for their tissue-specific expression of the lac $Z$ gene. All strains listed are $\mathrm{P}[\mathrm{lArB}]$ transposants, with the exception of $\mathrm{P}[\mathrm{ArB}] 6$, which is a transformant strain, and the $\mathrm{P}\left[1 a c, r y^{+} \mid \mathrm{A}\right.$ strains, which were recovered as transformants in a previous experiment (O'Kane and Gehring 1987). Some of these P[lac,ry ${ }^{+} \mid$A strains have already been described (Ghysen and $\left.\mathrm{O}^{\prime} \mathrm{Kane} 1989\right)$. The last digit of each transposant strain indicates the chromosome that carries the insertion. If it is followed by an uppercase $\mathrm{L}$, the insertion causes homozygous lethality; if it is followed by a lowercase 1 , the chromosome carrying the insertion is homozygous lethal, but we have not determined whether the lethality is due to the insertion (see text). Stage refers to the earliest stage of embryogenesis that $\beta$-galactosidase expression was observed. A slash $/ /$ in the cytological map position indicates that the insertion maps at the boundary of the two divisions given. If two divisions are not separated by a slash, the insert may map anywhere within them. Some strains mark additional tissues particularly well: These other tissues or organs are shown in italics in Other tissues and remarks. When only part of the tissue listed in the left-most column of the table expresses $\beta$-galactosidase, a more precise description is given in Other tissues and remarks (underlined), which also contains a description of the rest of the staining pattern. Abbreviations: (AMG) Anterior midgut; (AP) anal pads; (AS) amnioserosa; (B) brain; (Cl) clypeolabrum, (D) dorsal; (DL) dorsolateral; (EP) epidermis; (ES) esophagus; (FB) fat body; (FG) foregut; $(\mathrm{GC})$ gastric caecae; $(\mathrm{GON})$ gonad; $(\mathrm{H})$ head, usually cephalic sensory structures; (HG) hindgut; (HT) heart; (MEC) mesectoderm; (Mes) mesoderm; (MG) midgut; (MNC) median nerve cord; (MT) Malpighian tubules; (Mu) muscles; (Pens) subset of central nervous system; (PH) pharynx; (PMG) posterior midgut; (PNS) peripheral nervous system; (PS) posterior spiracles, (PV) proventriculus; (RG) ring gland; (SegB) segment boundary; (SG) salivary glands; (Sp) special repeated epidermal pattern, described in text; $(\mathrm{Tr})$ trachea; $(\mathrm{VM})$ visceral mesoderm; (VNC) ventral nerve cord; (Y) yolk cells.

a Approximate map position.

b Pattern and map position same as $\mathrm{P}\left[\mathrm{lac}, \mathrm{ry}^{+}\right] \mathrm{A} 30\left(\mathrm{O}^{\prime} \mathrm{Kane}\right.$ and Gehring 1987).

c For figure, see Wilson et al. (1989).

d For figure, see O'Kane and Gehring (1987).

e Strain carries two $\mathrm{P}[\mathrm{lArB}]$ insertions.

This aspect of staining pattern not shown in figure.

cells that are located in the ventral nerve cord. Indeed, numerous other strains show $\beta$-galactosidase expression in subsets of cells in the CNS that remain to be identified (e.g., Fig. 2DD).

In several transposants, a specific cell lineage appears to be stained during its differentiation. This would need to be verified in most cases by following the stained cells through development in more detail. However, there are some examples where the lineage of the marked cells has been characterized previously and can be correlated with the $\beta$-galactosidase staining pattern.
For example, in transposant $\mathrm{A} 490.2 \mathrm{M} 3$, one can easily follow the cells that will give rise to the midgut (Fig. 2D, $\mathrm{E}$, and F). At stage 10, the anterior and posterior midgut primordia can be seen clearly as two blocks of cells (Fig. $2 \mathrm{D}$; for staging and description of embryogenesis, see Campos-Ortega and Hartenstein 1985). These cells move toward each other until they fuse at $\sim 60 \%$ of egg length at stage 13 |where $0 \%$ of egg length represents the posterior pole; Fig. 2E). Specific staining in the midgut still is observed at stage 17 (Fig. 2F). A second example of a lineage marker is shown in Figure 2, P, Q, and R. The 
only tissue that stains in embryos of this transposant, A176.1M2, is the visceral mesoderm that gives rise to the visceral musculature. $\beta$-Galactosidase expression is seen first at stage 12 in two bilaterally symmetrical, longitudinal stripes. Each stripe, which is several cells wide, is composed of a series of strongly staining transverse bands interspersed by more weakly staining ones. Four partly segmented stripes have appeared by stage 13 (see Fig. 2P), and four lines of nuclei can be seen along the developing midgut at stage 15 (see Fig. 2Q). These nuclei continue to line the outer circumference of the midgut epithelium as development proceeds (stage 17, see Fig. 2R).

\section{Transposants carry single insertions}

Insertion strains carrying a single $P$ element are readily amenable to a genetic and molecular analysis (Cooley et al. 1988). Because we intended to study some transposants in more detail and our staining data reveal that many transposant strains express $\beta$-galactosidase in remarkably complex spatially and temporally regulated patterns, it was important to establish whether the transposants carry single or multiple insertions. Therefore, we decided to map cytologically the P elements in 68 insertion strains $[58 \mathrm{P}(\mathrm{lArB})$ transposants and 10 $\mathrm{P}\left[\right.$ lac, $\left.\mathrm{ry}^{+}\right] \mathrm{A}$ transformants recovered by $\mathrm{O}^{\prime}$ Kane and Gehring (1987)]. Most of these strains were chosen because they stained certain tissues particularly strongly, whereas a few were selected because they exhibit a homozygous recessive phenotype.

Preliminary evidence already suggested that many transposant strains contained single insertions because few individual male progeny of jumpstart males carried insertions on both the second and third chromosomes (see Materials and methods). Cytological mapping of the insertions confirmed that almost all strains carry a single insertion (data not shown); only one strain was shown to carry two insertions, and these are on the same chromosome. This indicates that even complex staining patterns seen in some transposants result from the effects of genomic regulatory elements on a single $\mathrm{P}$ element.

The $\mathrm{P}[\mathrm{ArB}]$ insertions essentially are scattered throughout the genome; however, there are four examples where two independently isolated transposants carry insertions at the same cytological location and show very similar $\operatorname{lac} Z$ expression patterns (data not shown). This suggests that there are some sites where $P$ elements insert preferentially, as has been reported previously. All transposons are integrated in euchromatic chromosomal locations, which is also in agreement with previous observations (for review on site specificity, see Engels 1988).

Some $\beta$-galactosidase staining patterns correlate with the known expression pattern of genes that map nearby

Our results suggest that strains carrying single insertions detect many different regulatory elements and that these elements are highly tissue specific in a substantial number of cases. Furthermore, in a few transposants, the
lacZ expression pattern is reminiscent of the known expression pattern of a gene identified previously. Therefore, we undertook a literature search for genes mapping at sites of $\mathrm{P}[\mathrm{lArB}]$ insertions to determine whether their expression pattern might correlate with the lac $Z$ expression pattern of the corresponding transposant (Lindsley and Zimm 1985, 1986; Tearle and Nüsslein-Volhard 1987; Merriam 1988). Five different transposants came to our attention: A208.1M2, mapping at 24D, A109.1F2 at $25 \mathrm{~B} / \mathrm{C}, \mathrm{A} 183.1 \mathrm{~F} 2$ at $36 \mathrm{E}, \mathrm{A} 405.1 \mathrm{M} 2$ at $33 \mathrm{~A}$, and $\mathrm{A} 140.1 \mathrm{~F} 3$ at $85 \mathrm{D} / \mathrm{E}$, and one transformant strain $\mathrm{P}\left[\right.$ lac, $\left.r \mathrm{y}^{+}\right] \mathrm{A} 63$ at $97 \mathrm{D}$.

The $\beta$-galactosidase expression pattern of transposant Al83.1F2 (36E) is very similar to the expression pattern of the fasciclin III gene, which also maps at 36E (Patel et al. 1987). The staining pattern of another transposant strain, A109.1F2 (25B/C) resembles the distribution of transcripts of the collagen type IV gene that maps at 25B (Mirre et al. 1988). In Wilson et al. (1989), we demonstrate that $\mathrm{P}[\mathrm{lArB}]$ indeed has inserted into the corresponding loci in these strains.

The expression pattern of $\mathrm{P}\left[1 a c, r y^{+}\right] \mathrm{A} 63$ (97D) shows striking similarities to the zygotic expression pattern of Toll, which also maps on the third chromosome at 97D (Gerttula et al. 1988). Tissues that express both $1 a c Z$ and Toll include the anterior and posterior midgut, foregut, hindgut, mesectoderm, salivary glands, the dorsal vessel, and epidermal cells just posterior to the segmental boundary (see Fig. 3A and B). However, the two expression patterns are not identical because unlike $\beta$-galactosidase, Toll transcripts also are found in preblastoderm embryos, somatic muscles, and tracheal placode invaginations (see Gerttula et al. 1988). Flies homozygous for the chromosome carrying this insertion are viable and fertile. By remobilizing the $P$ transposon using the E\#2 strain carrying the stable transposase gene, we recovered strains derived from the $\mathrm{P}\left[1 a c, r \mathrm{y}^{+}\right] \mathrm{A} 63$ flies carrying

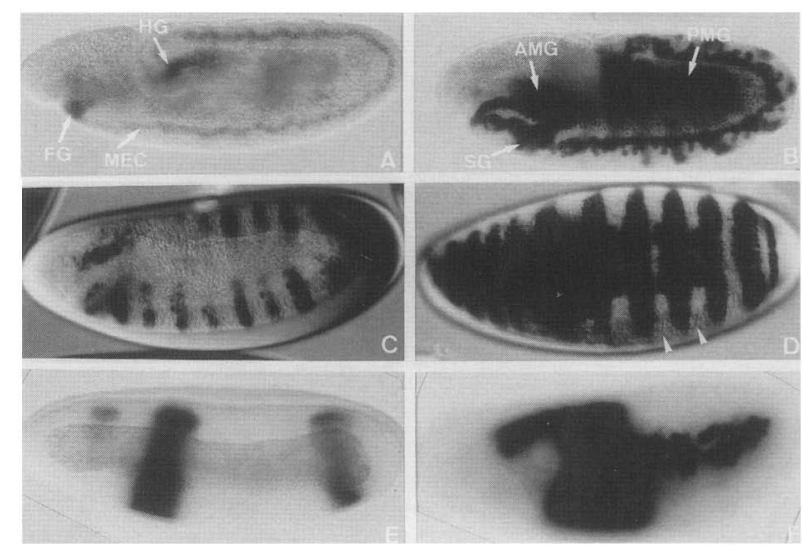

Figure 3. Embryonic transposant staining patterns that reflect the expression pattern of nearby genes. Embryos were stained for $\beta$-galactosidase activity, as described in Materials and methods $\left(A\right.$ and $B \mid \mathrm{P}\left[l a c, r y^{+}\right] \mathrm{A} 63$, which maps near Toll, at stages 10 and 12 , respectively. $(C$ and $D)$ A208.1M2, which maps near slp, at stages 11 and 16 , respectively; some segmental boundaries are marked by arrowheads. $(E$ and $F)$ A405.1M2, which maps near spalt, at stages 6 and 10, respectively. Abbreviations are as in Table 3. 
third chromosomes that lost the $\mathrm{ry}^{+}$marker. One of these strains does not complement the female sterility of a recessive Toll allele (Toll ${ }^{5 B R E Q}$; see Tearle and Nüsslein-Volhard 1987), strongly suggesting that the $\mathrm{P}[\mathrm{lArB}]$ excision event has created a Toll mutation in this case. Therefore, it is likely that $\mathrm{P}\left[1 a c, r y^{+}\right] \mathrm{A}$ has inserted near or within the Toll gene.

Embryos of transposant A140.1F3 (85D/E) show $\beta$-galactosidase expression in all tissues (data not shown), an expression pattern that corresponds to the embryonic transcript distribution of Dras 1 (85D), a gene that shares homology with the vertebrate Ha-ras oncogene (Neuman-Silberberg et al. 1984; Segal and Shilo 1986). In third-instar larvae, the transcripts of Dras1 are localized to the brain, imaginal discs, and gonads (Segal and Shilo 1986). The same tissue distribution of $\beta$-galactosidase activity is observed in third-instar larvae of transposant A140.1F3 (Gibson and Gehring 1990). A more accurate cytological mapping with appropriate probes revealed that both the insertion and the Dras1 gene are located at the distal end of $85 \mathrm{D}$.

Three transposants express $\beta$-galactosidase at the cellular blastoderm stage in a spatially restricted fashion. The insertions in two of these transposants map at positions of known genes that play a role in early pattern formation. Transposant A405.1M2(33A) shows a staining pattern similar to the transcript distribution of the spalt gene, which maps at 33A1-2 (Frei et al. 1988). At cellular blastoderm, two intensely stained stripes are observed; the anterior stripe $(58-70 \%$ of egg length) is slightly wider than the posterior one $18-18 \%$; see Fig. $3 \mathrm{E}$ and $\mathrm{F} /$ and appears first. Another group of cells expresses $\beta$-galactosidase in the dorsal part of the presumptive head region at $\sim 85 \%$ of egg length. Both during and for some time after the cellular blastoderm stage, the dynamics of the staining pattern and the areas where staining is observed are comparable to those described for the transcript distribution of spalt (Frei et al. 1988). However, unlike spalt, we observe no $\beta$-galactosidase expression in the most posterior end of the cellular blastoderm embryo. Furthermore, there is no staining in the repeated pattern seen for spalt during germ-band extension.

A second transposant, A208.1M2 $(24 \mathrm{D})$, carries a $\mathrm{P}[1 \mathrm{ArB}]$ insertion at the location of sloppy-paired (slp), an essential pair-rule gene mapping at 24C-D (NüssleinVolhard et al. 1984). This gene has not been cloned yet, but $s l p$ mutations are known to affect the naked cuticle in every other segment ( $\mathrm{T} 2, \mathrm{~A} 1, \mathrm{~A} 3, \mathrm{~A} 5$, and $\mathrm{A} 7)$ of firstinstar larvae. The staining pattern in A208.1M2 (24D) embryos has characteristics that are reminiscent of the expression pattern of a pair-rule or a segment polarity gene (Fig. 3C and D). In the late cellular blastoderm stage, a broad band of $l a c Z$ expression is observed in the head region of A208.1M2 embryos. Seven stripes then appear early in gastrulation, one in every other segment. During early germ-band extension, an additional seven stripes rapidly become visible; within the thoracic and abdominal segments $\beta$-galactosidase is expressed at higher levels in T2, Al, A3, A5, and A7 (see Fig. 3C). By the end of germ-band extension, the 14 stripes are of similar intensity. The stripes are located in the middle of each segment (see Fig. 3D), which corresponds to the zone of naked cuticle in first-instar larvae.

\section{Discussion}

We generated and analyzed $>500$ transposant strains that carry single insertions of a novel P-element enhancer detector. These strains show a great variety of $\beta$-galactosidase expression patterns, reflecting the influence of many different genomic regulatory elements on the $\mathrm{P}-\mathrm{lac} Z$ reporter gene. P-element-mediated enhancer detection is a very efficient technique for generating tissue- and cell-specific markers. About $65 \%$ of transposants show spatially restricted embryonic staining patterns, and many of these mark different cells and tissues. These observations indicate that a great variety of different regulatory elements can be identified with enhancer detectors. Our mapping and staining data show that the $\mathrm{P}[\mathrm{ArB}]$ transposon inserts at diverse locations, although there may be some limited insertion site preference. It has been estimated that a saturation mutagenesis with P elements would disrupt $50 \%$ of all Drosophila genes (for discussion, see Kidwell 1986). Therefore, we expect that many more transposants with novel expression patterns are yet to be isolated in future enhancer detector screens.

\section{$P[1 A r B \mid$ marker strains facilitate the study of development in Drosophila}

Many transposants that we isolated can be used for various purposes as marker strains for internal embryonic tissues and cells. Some of these stain specific cells that are otherwise difficult or impossible to identify. Indeed, in a number of transposants, cell types can be distinguished that have not been recognized previously to our knowledge (see, e.g., Fig. $2 \mathrm{U}, \mathrm{V}$, and W). This is particularly true for cells in the CNS and the head (see Fig. $2 \mathrm{~W}$ and $\mathrm{DD}$ ). The details of embryonic development in these tissues essentially have been inaccessible to a developmental and genetic analysis because of the lack of suitable markers. It should now be possible to analyze the phenotypes of mutations that affect the head and the nervous system by observing the effects these mutations have on the various cell-specific staining patterns. Many transposants also provide regional markers in the imaginal discs and brain of third-instar larvae /Gibson and Gehring 1990) and adult tissues such as ovaries (Fasano and Kerridge 1988; Grossniklaus et al. 1989).

It is clear that additional applications exist for this marker system in the study of Drosophila development. For example, there are a number of ways to use the markers in the study of cell lineages. One obvious approach assumes that cells staining early in development are precursors of cells that stain later in the same strain. To be substantiated for a particular strain, this approach would require careful observation and analysis of both the normal pattern and the changes in this pattern in mutants that are known to affect the marked cells (see, e.g., Ghysen and O'Kane 1989|. Other approaches using 
$\mathrm{P}[1 \mathrm{ArB}]$ transposants may be employed to study the lineage of a specific group of cells. Ring $X$ chromosomes may be generated that carry an early, nonmaternal PlacZ marker for these cells. The loss of such a chromosome in female embryos should allow one to determine whether adjacent cells are derived from the same or different cells. Finally, it also may be possible to use X-rayinduced mitotic recombination to study cell lineages. The most serious drawback of this approach is that the $\beta$-galactosidase may remain active for several hours in cells that have lost the insertion, a phenomenon that has been called perdurance (Garcia-Bellido and Merriam 1971).

In another interesting application, the dominant marker strains may also be used genetically to characterize all of the embryos resulting from a cross. This would involve selecting a suitable set of markers on the chromosomes of two parent flies. For example, we generated marked second and third balancer chromosomes, in which $\beta$-galactosidase is expressed from an early stage of embryonic development (e.g., Fig. 2GG and the last three strains in Table 3). In a cross between flies that carry a lethal mutation balanced with one of these 'blue balancers' it is possible to identify the $25 \%$ of embryos that are homozygous for the lethal mutation, because they are the only embryos that do not stain. By using a male parent carrying an appropriate insertion on the $\mathrm{X}$ chromosome one also can identify unambiguously male and female embryos long before sexual differentiation has taken place. Alternatively, this could be done with strains that show a sex-specific pattern of expression, if they were to be isolated in a future screen. Such strains would also prove useful in sex-determination studies.

\section{Enhancer detectors may identify the regulatory elements of Drosophila genes}

The remarkable frequency with which spatially regulated patterns are observed in transposants poses an obvious question: What fraction of the detected regulatory elements normally control adjacent Drosophila genes? Our cytological mapping data indicate that some of the regulatory elements control genes in the region of the insertion. Currently, 6 of 68 insertions examined map to positions of genes that have or probably have a similar expression pattern to the staining pattern in the transposant strain. In two of these cases, a molecular analysis has confirmed that $\mathrm{P}[1 \mathrm{ArB}]$ has inserted into the corresponding genes fasciclin III and collagen type IV /Wilson et al. 1989).

The staining patterns of three other insertion strains, $\mathrm{P}\left[\right.$ lac, ry $\left.{ }^{+}\right] \mathrm{A} 63$ (97D), A405.1M2 (33A), and A140.1F3 (85D), are similar to the transcript distributions of Toll (97D), spalt (33A), and Dras1 (85D), respectively. In the case of P[lac,ry $\left.{ }^{+}\right] \mathrm{A} 63$ (97D), we observed that embryos do not stain in all tissues reported by Gerttula et al. (1988) for Toll. Moreover, although Toll is expressed ma. ternally, we have not observed staining before the cellular blastoderm stage and have found no staining in nurse cells of female ovaries (U. Grossniklaus, unpubl.). However genetic evidence demonstrates that the inser- tion is in or near the Toll gene. These observations suggest that the P-transposase promoter is influenced by some, but not all, of the regulatory elements of the Toll gene. Similarly, the embryonic staining pattern of transposant A405.1M2 (33A) corresponds well, but not exactly, to the transcript distribution of the spalt gene (Frei et al. 1988). A molecular and genetic analysis has shown recently that the insertion is in the neighborhood of the spalt gene (J. Bernholz, pers. comm). For Al40.1F3 (85D), it appears that $\mathrm{P}[\mathrm{lArB}]$ has detected one or more regulatory elements that control the Dras1 gene, although we have not characterized this transposant further.

In another transposant, A208.1M2 (24D), the lacZ expression pattern correlates strongly with the mutant phenotype of the slp pair-rule gene that maps near the insertion. Although this gene has not been cloned yet, recent genetic evidence suggests that the insertion does indeed lie close to the slp gene (R.K. Pearson, pers. comm.).

\section{Implications of the P-element enhancer detector screen}

Our results suggest that enhancer detectors can be used to identify genes on the basis of their expression pattern. In Wilson et al. (1989), molecular evidence is presented that this is indeed the case. Both highly specific and complex staining patterns seem to reflect the distribution of transcripts from a single gene. Even regulatory elements that drive the expression of a neighboring gene in all or most embryonic cells are detected (e.g., Dras1). We conclude that the enhancer detector appears to show no strong preference toward particular regulatory elements. The range of staining patterns therefore, may be considered to reflect, at least partly, the range of expression patterns of genes in the Drosophila genome. If this is assumed to be the case, we can make a number of observations regarding the general expression patterns of genes during development.

Our data show that $\sim 65 \%$ of all identified regulatory elements are active in specific embryonic tissues. This suggests that only a minority of genes are expressed in all cells during Drosophila embryogenesis. Even among the $30 \%$ of all transposants that do express $\beta$-galactosidase in all parts of the embryo, $>50 \%$ still express it preferentially in specific tissues. We have noted also a remarkably high proportion of staining patterns that include regions of the head, CNS, or PNS. This is probably a reflection of the complexity of gene expression required to establish the great variety of cell types and connections between different cells within these regions. Relatively few transposants express $\beta$-galactosidase in mesodermal and epidermal cells, suggesting that many less tissue-specific genes are required for the development of these tissues.

The results indicate that many individual genes are expressed in several, apparently unrelated cell types or tissues. It has been suggested that complex expression patterns of this kind may be achieved by the combinatorial action of trans-acting factors and cis-acting elements. The resulting regulatory network may lead to a gene being expressed in tissues in which it is not re- 
quired because other genes controlled by the same trans-acting factors must be expressed in these particular tissues (Dickinson 1988). Therefore, a gene product may be required only in some of the tissues in which it is expressed or in which $\beta$-galactosidase is expressed in the corresponding transposant. This hypothesis may be tested in some transposant strains by generating deletions around the region of insertion and studying the resulting phenotypic effect (see Wilson et al. 1989). The enhancer detector method should be useful for investigating the building blocks from which cis-acting regulatory elements are formed and how they are controlled by trans-acting factors.

In summary, the P-element-mediated enhancer detection system described here is a multipurpose tool with which to analyze development in Drosophila. We used it to generate markers that should allow rapid screening for mutants that affect any marked tissue of interest. Furthermore, the enhancer detector reveals the expression pattern of genes near which it inserts and therefore may be used to isolate genes that are expressed specifically in any tissue or cells of interest (Wilson et al. 1989). The efficiency with which transposants with novel staining patterns have been generated suggests that future screens will lead to the identification of many more additional tissue- and cell-specific markers and genes. This should allow Drosophila to be more conveniently used as a model eukaryotic system for the analysis of developmental processes that have been difficult to study in the past.

\section{Materials and methods}

Detailed protocols for many of the techniques described are available on request (see Wilson et al. 1990). Most of the fly strains and detailed lists of staining patterns and cytological mapping positions are available from the Howard Hughes P-element Drosophila Stock Center (Bloomington, Indiana).

\section{Cytological mapping}

Biotin labeling of DNA probes and in situ hybridization to larval polytene chromosomes were performed as described by Langer-Safer et al. (1982). In some cases, the peroxidase reaction was followed by amplification of the signal using a DAB (diaminobenzidine) silver amplification kit (Amersham). For insertions on the first and third chromosomes, the biotin-labeled plasmid p45 [carrying the 7.2-kb HindIII fragment containing the $\mathrm{ry}^{+}$gene cloned in Bluescript (Rubin and Spradling 1983) was hybridized to salivary gland spreads prepared from larvae homozygous for each insertion. If the chromosome carrying the insertion was homozygous lethal, balanced heterozygotes were outcrossed to $r y^{506}$ flies and salivary gland spreads prepared from the progeny; spreads with a balancer chromosome (FM6 or $T M 3$ ) were discarded. Because of its complex cytology, insertions on the second chromosome balancer $\mathrm{CyO}$ were not mapped directly; DNA flanking each insertion was cloned first in E. coli by plasmid rescue (see Wilson et al. 1989), and the cloned DNA then was used to probe spreads of wild-type chromosomes.

\section{$\beta$-Galactosidase staining}

To process large numbers of strains, embryos were stained in the presence of $0.3 \%(\mathrm{vol} / \mathrm{vol})$ Triton X-100. Embryos were de- chorionated first, washed in water, blotted dry, and fixed for $15-20 \mathrm{~min}$ in fixing solution [a mixture of $100 \mathrm{ml}$ of $0.1 \mathrm{M}$ PIPES (pH 6.9), $2 \mathrm{~mm}$ EGTA, $1 \mathrm{~mm} \mathrm{MgSO}_{4}$, and $25 \mathrm{ml}$ of $37 \%$ formaldehyde]. Then they were incubated from $1 \mathrm{hr}$ to overnight (depending on staining intensity) in staining solution [10 mM sodium phosphate $(\mathrm{pH} 7.2), 150 \mathrm{mM} \mathrm{NaCl}, 1 \mathrm{mM} \mathrm{MgCl}_{2}$, $6.1 \mathrm{mM}$ potassium ferricyanide, $6.1 \mathrm{mM}$ potassium ferrocyanide, $0.2 \% \mathrm{X}$-Gal (5-bromo-4-chloro-3-indolyl- $\beta$-D-galactoside); the $\mathrm{X}$-Gal is added shortly before incubation from an $8 \%$ stock solution in DMSO [modified from Simon et al. 1985)]. After staining, embryos were washed two to three times in PBS/Triton to remove crystals of X-Gal and mounted. They were viewed with bright-field or Nomarski optics on a Zeiss standard microscope and photographed using Ektachrome 50 slide film at ASA 40. The staining pattern of each strain was recorded on a table before the preparation deteriorated.

\section{Generation of insertion strains}

The plasmid P-1ArB, carrying the $r y^{+}$eye color marker, and the helper P-element p $\pi 25.7 \mathrm{wc}$ (Karess and Rubin 1984) were injected in $r y^{506}$ embryos to generate transformants, as described in Hiromi et al. (1985). We selected a transposant with a $\mathrm{P}[\mathrm{ArB}]$ second chromosome insertion at $54 \mathrm{~A} / \mathrm{B}$ for the jumpstart experiment (Cooley et al. 1988). This strain was balanced and crossed to the E\#2 stock that carries a stable genomic transposase source $\mathrm{P}\left[\mathrm{ry}^{+} \Delta 2-3\right]$ (99B) (Robertson et al. 1988). This and all further crosses were performed at $25^{\circ} \mathrm{C}$.

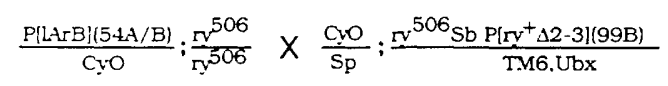

We screened for males having a specific genotype from the progeny of this cross. We refer to these males as jumpstart males. Single jumpstart males were mated to single females of two possible genotypes:

$$
\begin{aligned}
& \text { ơ } \frac{\mathrm{ftz}^{9 \mathrm{H} 34} \mathrm{ry}^{506} \mathrm{e}^{\mathrm{s}}}{\text { TM2. ry Ubx }} \\
& \text { (Cross A) } \\
& X \delta \frac{P[\mid A r B][54 A / B)}{C y O} ; \frac{\left.r^{506}{ }_{S b ~ P[r y}{ }^{+} \Delta 2-3\right](99 B)}{r y 506} \\
& \text { ơ } \frac{r^{506} e}{\text { ry506e }} \\
& \text { (Cross B) }
\end{aligned}
$$

Mobilization of the P[IArB $]$ transposon takes place in the germ-line cells of the jumpstart males, and some progeny will be produced that have a $\mathrm{P}[\mathrm{IArB}]$ insertion at a new location. A proportion of these progeny can be identified by screening for flies that carry neither the $\mathrm{P}[\mathrm{IArB}](54 \mathrm{~A} / \mathrm{B})$ chromosome nor the $S b$-marked chromosome containing the transposase gene, but that contain a P $[\mathrm{lArB}]$ insertion and are therefore ry ${ }^{+}$The chromosomes that may contain a new insertion are indicated with an asterisk $(*)$ in the subsequent crosses.

To recover insertions on the autosomes of male transposants, single males were mated to appropriate females:

$$
\begin{aligned}
& \delta^{\prime} \frac{\mathrm{X}}{\mathrm{Y}} ; \frac{\mathrm{CVO}^{*}}{+} ; \frac{\mathrm{ry} 506^{*}}{\mathrm{TM} 2 . \mathrm{ry} \mathrm{Ubx}(\mathrm{or} \mathrm{ftz}}{ }^{9 \mathrm{H} 34_{\mathrm{ry}}}{ }^{\left.506_{\mathrm{e}} \mathrm{s}\right)} \\
& \text { ơ } \frac{\mathrm{ftz}^{9 \mathrm{H} 34} \mathrm{rv}^{506} \mathrm{e}^{\mathrm{s}}}{\mathrm{TM} 3 \mathrm{Sb} \mathrm{ry}} \mathrm{X} \\
& \delta \frac{X}{Y}: \frac{C y O}{t} ; \frac{\text { ry } 506^{*}}{r y 506 \mathrm{e}} \\
& \text { (from Cross B) }
\end{aligned}
$$

Examination of the progeny from this cross allowed identification of the chromosome that did not contain a $\mathrm{P}[\mathrm{ArB}]$ insertion. Less than $2 \%$ of the transposants carried an insertion on both the second and third chromosomes. One transposant did not contain $\mathrm{P}[\mathrm{lArB}]$, either on the second or third chromosome; 
it was assumed to be a fourth chromosome insertion strain. Insertions on the third chromosome were balanced with the TM3, $S b r^{r k}$ chromosome, and insertions on the $\mathrm{CyO}$ balancer chromosome were balanced subsequently with the $b A d h^{n} \mathrm{cn}$ (carrying an unknown lethal) chromosome.

To recover insertions on the $\mathrm{X}$ chromosome and the autosomes of female transposants, single females from cross A were mated to the following males:

$$
\text { ơ } \mathrm{x}^{*}: \frac{\mathrm{CyO}}{+} ; \frac{\mathrm{ry} 506^{*}}{\mathrm{TM} 2, \mathrm{ry}} \mathrm{rk} \quad \text { of } \frac{\mathrm{FM} 6}{\mathrm{Y}}: \frac{\mathrm{ry}^{506}}{\mathrm{ry}^{506}}
$$

Examination of the progeny of this cross usually allowed identification of the chromosome carrying the insertion. First chromosome insertions were balanced already with the FM6 chromosome; second and third chromosome insertions were balanced subsequently with the $b A d h^{n} c n$ (lethal unknown) and the TM3, $S b$ ry ${ }^{\mathrm{rk}}$ chromosomes, respectively.

Approximately 820 flies carrying $\mathrm{P}[\mathrm{lArB}]$ insertions at a new location were generated from crosses with 840 individual jumpstart males. Of these 820 flies, we finally analyzed 624 in detail. We discarded only $13 \%$ of the 624 flies, because they most likely carried an insertion at the same location as a sibling strain derived from the same jumpstart male (see Results).

\section{Remobilizing $P[L A r B]$}

To ascertain whether a lethal or a visible mutation on the third chromosome is caused by the $\mathrm{P}[\mathrm{lArB}]$ insertion, we performed the following crosses:

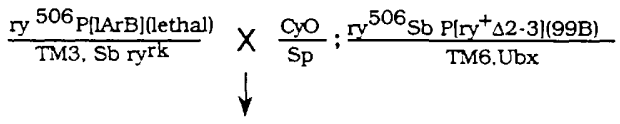

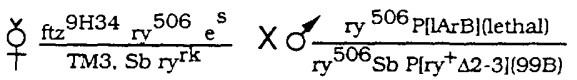

$$
\begin{aligned}
& \text { (individual jumpstart males) }
\end{aligned}
$$

The insertions are often excised precisely and lost in the germ-line cells of the jumpstart males. Progeny of a single jumpstart male were mated as follows:

$$
\frac{\mathrm{ry} 506 \Delta \mathrm{P}[\mathrm{Ar} \mathrm{B}] 1}{\mathrm{TM} 3, \mathrm{Sb} \mathrm{ry}} \times \frac{\mathrm{ry}^{\mathrm{rk}} 506 \Delta \mathrm{P}[\mathrm{LArB} \mid 2}{\mathrm{TM} 3, \mathrm{Sb} \mathrm{ry}} \quad \begin{gathered}
\text { (single brother and } \\
\text { sister matings) }
\end{gathered}
$$

Recovery of $r y \mathrm{Sb}^{+}$flies indicates that the insertion is responsible for the lethal or mutant phenotype if no other P transposons are present in the genome (see Results). Other studies failed to detect mobilization of non-P transposons by $\mathrm{P}$ transposase (Eggleston et al. 1988).

\section{Cosegregation of $P[L A r B]$ and the lethal phenotype}

To provide additional and independent evidence for cosegregation of $\mathrm{P}[\mathrm{ArB}]$ and a lethal mutation, the $\mathrm{P}[\mathrm{ArB} \mid$-containing chromosomes in six lethal strains were allowed to recombine with the $r y^{506}$ chromosome, and the putative recombinant chromosomes carrying $\mathrm{P}[1 \mathrm{ArB}]$ were balanced over $T M 3, S b r y^{r k}$. Then individual balanced chromosomes were tested for the presence of a lethal mutation. If viable homozygous $\mathrm{ry}^{+}$flies are recovered, the $\mathrm{P}[\mathrm{lArB}]$ insertion cannot be responsible for the lethal mutation. More than 125 individual chromosomes were screened for each strain, thus allowing the lethal mutations to be localized to within $1 \mathrm{CM}$ of the $\mathrm{P}[\mathrm{lArB}]$ insertion.

\section{Stocks}

Most balancer chromosomes are described in Lindsley and Grell (1968). The TM2, ry chromosome was a gift from J. Merriam. The $T M 3, S b r y^{r k}$ was a gift from R. Karess.

\section{Acknowledgments}

We give special thanks to Hugh Robertson, Bill Engels, and their co-workers for making the $\Delta 2-3$ transposase strains so widely available before publication. Our thanks also go to BenZion Shilo for the Dras1 clone, and to Christiane Nüsslein-Volhard, Thom Kaufman, Ruth Lehmann, Bill Gelbart, Jose Campos-Ortega, John Merriam, and the Umeå Stock Center for mutant fly stocks. We are grateful to Greg Gibson and Juliane Bernholz for sharing unpublished data. We thank Walter Keller for his special interest and support, Urs Kloter for giving us confidence in our cytological mapping data, and Juliane Bernholz for providing Figure 3C. Thanks also go to Maria Rizzieri for preparing abundant fly food. Finally, we thank Anthony Percival-Smith, Greg Gibson, Alexander Schier, Leslie Pick, Ylva Engström, Pamela Jones, Gisela Nielson, and Markus Affolter for helpful comments on the manuscript. This work was supported by a NATO fellowship to H.B., fellowships from EMBO and the Roche Foundation to C.O.K., a Royal Society exchange fellowship to C.W., and American Cancer Society fellowship to R.K.P., the Swiss National Science Foundation, and the Kantons of Basel Stadt and Basel-Landschaft.

\section{References}

Bodmer, R., S. Barbel, S. Sheperd, J.W. Jack, L.Y. Jan, and Y.N. Jan. 1987. Transformation of sensory organs by mutations of the cut locus of D. melanogaster. Cell 51: 293-307.

Campos-Ortega, J.A. and V. Hartenstein. 1985. The embryonic development of Drosophila melanogaster. Springer-Verlag, Berlin.

Cooley, L., R. Kelley, and A. Spradling. 1988. Insertional mutagenesis of the Drosophila genome with single P-elements. Science 239: 1121-1128.

Dickinson, N.J. 1988. On the architecture of regulatory systems: Evolutionary insights and implications. BioEssays 8: 204-210.

Engels, W.R. 1988. P elements in Drosophila. In Mobile DNA (ed. D.E. Berg and M.M. Howe), pp. 437-484. American Society for Microbiology, Washington, D.C.

Eggleston, W.B., D.M. Johnson-Schlitz, and W.R. Engels. 1988. P.M hybrid dysgenesis does not mobilize other transposable element families in D. melanogaster. Nature 331:368-370.

Fasano, L. and S. Kerridge. 1988. Monitoring positional information during oogenesis in adult Drosophila. Development 104: $245-253$.

Frei, E., R. Schuh, S. Baumgartner, M. Burri, M. Noll, G. Jürgens, E. Siefert, U. Nauber, and H. Jäckle. 1988. Molecular characterization of spalt, a homeotic gene required for head and tail development in the Drosophila embryo. EMBO /. 7: 197-204.

Garcia-Bellido, A. and J. Merriam. 1971. Genetic analysis of cell heredity in imaginal discs of Drosophila melanogaster. Proc. Natl. Acad. Sci. 65: 2222-2226.

Gehring, W.J. and Y. Hiromi. 1986. Homeotic genes and the homeo-box. Annu. Rev. Genet. 20: 147-173.

Gerttula, S., J. Yishi, and K.V. Anderson. 1988. Zygotic expression and activity of the Drosophila Toll gene, a gene required maternally for embryonic dorsal-ventral pattern formation. Genetics 119: 123-133.

Ghysen, A. and C. O'Kane. 1989. Neural enhancer-like elements as specific cell markers in Drosophila. Development 105: $35-52$.

Gibson, G. and W. Gehring. 1990. P-element-mediated enhancer detection in imaginal discs and third instar larval brains of Drosophila melanogaster. Drosophila Inf. Serv. 69 
Grossniklaus, U., H.J. Bellen, C. Wilson, and W. Gehring. 1989. P-element-mediated enhancer detection applied to the study of oogenesis in Drosophila. Development (in press).

Hiromi, Y., A. Kuroiwa, and W.J. Gehring. 1985. Control elements of the Drosophila segmentation gene fushi tarazu. Cell 43: 603-613.

Jan, L.Y. and Y.N. Jan. 1982. Antibodies to horseradish peroxidase as specific neuronal markers in Drosophila and in grasshopper embryos. Proc. Natl. Acad. Sci. 79: 2700-2704.

Jürgens, G., E. Wieschaus, C. Nüsslein-Volhard, and $H$. Kluding. 1984. Mutations affecting the pattern of the larval cuticle in Drosophila melanogaster. II. Zygotic loci on the third chromosome. Wilhelm Roux's Arch. Dev. Biol. 193:283-295.

Karess, R.E. and G.M. Rubin. 1984. Analysis of P transposable element functions in Drosophila. Cell 38:135-146.

Kidwell, M. 1986. P-M mutagenesis. In Drosophila, a practical approach (ed. D.B. Roberts), pp.59-78. IRL Press, Oxford, Washington, D.C.

Langer-Safer, P.R., M. Levine, and D.C. Ward. 1982. Immunological method for mapping genes on Drosophila polytene chromosomes. Proc. Nat1. Acad. Sci. 79: 4381-4385.

Lindsley, D. and E. Grell. 1968. Genetic variations of Drosophila melanogaster. Carnegie Inst. Washington Publ. No. 627.

Lindsley, D. and G. Zimm. 1985. The genome of Drosophila melanogaster. Part 1: Genes A-K. Drosophila Info. Serv. 62

- 1986. The genome of Drosophila melanogaster . Part 2: Lethals and maps. Drosophila Info. Serv. 64.

Lis, J.T., J.A. Simon, and C.A. Sutton. 1983. New heat shock puffs and $\beta$-galactosidase activity resulting from transformation of Drosophila with an hsp-70-lacZ hybrid gene. Cell 35: 403-410.

Merriam, J. 1988. The Drosophila clone list by chromosomal location. Dros. Info. Serv. 67: 111-136.

Mirre, C., J.-P. Cecchini, Y. Le Parco, and B. Knibiehler. 1988. De novo expression of a type IV collagen gene in Drosophila embryos is restricted to mesodermal derivatives and occurs at germ band shortening. Development 102: 369-376.

Neuman-Silberberg, F.S., E. Schejter, F.M. Hoffman, and B.-Z Shilo. 1984. The Drosophila ras oncogenes: Structure and nucleotide sequence. Cell 37: 1027-1033.

Nüsslein-Volhard, C., E. Wieschaus, and H. Kluding. 1984. Mutations affecting the pattern of the larval cuticle in Drosophila melanogaster. I. Zygotic loci on the second chromosome. Wilhelm Roux's Arch. Dev. Biol. 193: 267-282.

O'Kane, C.J. and W.J. Gehring. 1987. Detection in situ of genomic regulatory elements in Drosophila. Proc. Natl. Acad. Sci. 84: 9123-9127.

Patel, N.H., P.M. Snow, and C.S. Goodman. 1987. Characterization and cloning of fasciclin III: A glycoprotein expressed on a subset of neurons and axon pathways in Drosophila. Cell 48: $975-988$.

Robertson, H.M., C.R. Preston, R.W. Phillis, D.M. JohnsonSchlitz, W.K. Benz, and W.R. Engels. 1988. A stable source of P-element transposase in Drosophila melanogaster. Genetics 118: 461-470.

Rubin, G.M. and A.C. Spradling. 1983. Vectors for P-elementmediated gene transfer in Drosophila. Nucleic Acids Res. 11: $6341-6351$.

Segal, E. and B.-Z. Shilo. 1986. Tissue localization of Drosophila melanogaster ras transcripts during development. Mol. Cell. Biol. 6: 2241-2248.

Serfling, E., M. Jasin, and W. Schaffner. 1985. Enhancers and eukaryotic gene transcription. Trends Genet. 1: 224-230.
Simmons, M.J., J.D. Raymond, T.D. Laverty, R.F. Doll, N.C. Raymond, G.J. Kocur, and E.A. Drier. 1985. Chromosomal effects on mutability in the P-M system of hybrid dysgenesis in Drosophila melanogaster. Genetics 111: 869-884.

Simon, J.A., C.A. Sutton, R.B. Lobell, R.L. Galser, and J.T. Lis. 1985. Determinants of heat shock-induced chromosome puffing. Cell 40: 805-817.

Tearle, R. and C. Nüsslein-Volhard. 1987. Tübingen mutants and stocklist. Drosophila Info. Serv. 66: 209-269.

Thomas, J.B., S.T. Crews, and C.S. Goodman. 1988. Molecular genetics of the single-minded locus: A gene involved in the development of the Drosophila nervous system. Cell 52: $133-141$.

Wieschaus, F., C. Nüsslein-Volhard, and G. Jürgens. 1984. Mutations afffecting the pattern of the larval cuticle in Drosophila melanogaster III. Zygotic loci on the X-chromosome and the fourth chromosome. Wilhelm Roux's Arch. Dev. Biol. 193: 296-307.

Wilson, C., R.K. Pearson, H.J. Bellen, C.J. O'Kane, U. Grossniklaus, and W. Gehring. 1989. P-element-mediated enhancer detection: Isolation and characterization of developmentally regulated genes in Drosophila. Genes Dev. 3:1301-1333

Wilson, C., H.J Bellen, R.K. Pearson, C.J. O'Kane, Y. Engström, G. Gibson, U. Grossniklaus, and W. Gehring. 1989. The little blue book. Drosophila Info. Serv. 69 (in press). 


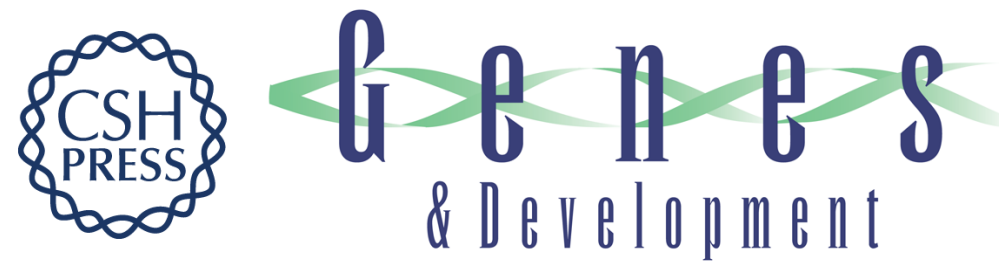

\section{P-element-mediated enhancer detection: a versatile method to study development in Drosophila.}

H J Bellen, C J O'Kane, C Wilson, et al.

Genes Dev. 1989, 3:

Access the most recent version at doi:10.1101/gad.3.9.1288

References This article cites 32 articles, 12 of which can be accessed free at:

http://genesdev.cshlp.org/content/3/9/1288.full.html\#ref-list-1

License

Email Alerting Receive free email alerts when new articles cite this article - sign up in the box at the top Service right corner of the article or click here.

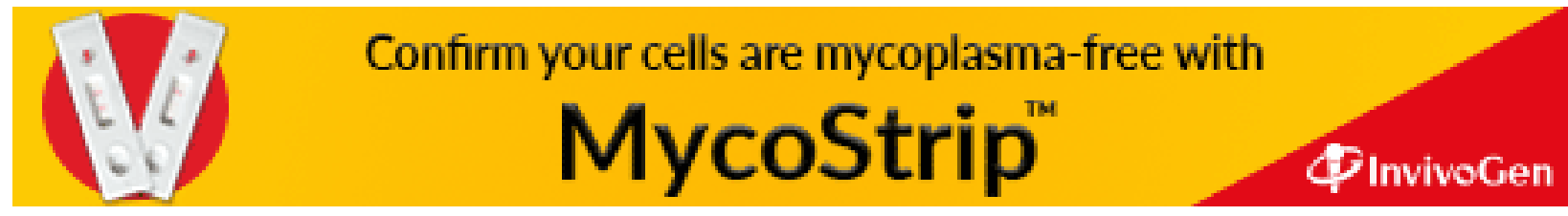

